\title{
Improved extracellular secretion of $\beta$-cyclodextrin glycosyltransferase from Escherichia coli by glycine supplementation without apparent cell lysis
}

\author{
Nik Ida Mardiana Nik-Pa, ${ }^{\mathrm{a}, \mathrm{b}}$, Suraini Abd-Aziz , Mohamad Faizal Ibrahimª , Noorjahan Banu \\ Mohamed Alitheen ${ }^{c}$, Norhayati Ramli ${ }^{*}$ \\ ${ }^{a}$ Department of Bioprocess Technology, Faculty of Biotechnology and Biomolecular Sciences, Universiti Putra Malaysia, 43400 UPM Serdang, \\ Selangor, Malaysia. \\ ${ }^{b}$ Section of Bioengineering Technology, Universiti Kuala Lumpur Branch Campus, Malaysian Institute of Chemical \& Bioengineering Technology, \\ Taboh Naning, 78000 Alor Gajah, Melaka. \\ 'Department of Cell and Molecular Biology, Faculty of Biotechnology and Biomolecular Sciences, Universiti Putra Malaysia, 43400 UPM \\ Serdang, Selangor, Malaysia.
}

Received 25th January 2019 / Accepted 5th April 2019

\begin{abstract}
The use of an effective inducer feeding strategy without causing cell lysis presents significant advantage to enhance the secretion of an enzyme to the culture medium of Escherichia coli. The cgt gene encoding $\beta$-cyclodextrin glycosyltransferase ( $\beta$-CGTase) was cloned into pQE30xa as an N-terminal Histagged protein and transformed into E. coli. The induction strategy was applied towards enhancing the extracellular secretion of the recombinant $\beta$-CGTase by increasing permeability of the outer membrane of E. coli. The supplementation of $1.2 \mathrm{mM}$ glycine following $2 \mathrm{~h}$ of fermentation at $37^{\circ} \mathrm{C}$ enhanced the activity of $\beta$-CGTase to $38.295 \mathrm{U} / \mathrm{mL}$, which was approximately 1.3 -fold higher than the control (without induction). Further flow cytometry analysis was adopted as a rapid and highly reproducible approach to determine the effect of glycine supplementation on the viability of E. coli cells. The supplementation of glycine did not contribute to apparent cell lysis, with no adverse effects on cell viability, hence indicating the effectiveness of glycine in enhancing the extracellular secretion of $\beta$-CGTase. The recombinant $\beta$ CGTase was then purified through a combination of diafiltration and Ni-NTA affinity chromatography with 18.4-fold increase in purity. An effective glycine feeding strategy could enhance the extracellular secretion of $\beta$-CGTase without adverse effects on cell viability. This strategy could be applied potentially to enhance the secretion of a recombinant protein to the culture medium from E. coli cells without having cell lysis.
\end{abstract}

Keywords: cell viability, cyclodextrin glycosyltransferase, extracellular secretion, glycine, inducer, membrane permeability

\section{INTRODUCTION}

Cyclodextrin glycosyltransferase (CGTase; EC 2.4.1.19) is a member of the $\alpha$-amylase family, also known as glycosyl-hydrolases which catalyse the formation of cyclodextrins (CDs) from starch

* Author for correspondence: Norhayati Ramli, Department of Bioprocess Technology, Faculty of Biotechnology and Biomolecular Sciences, Universiti Putra Malaysia, 43400 UPM Serdang, Selangor, Malaysia. Email yatiramli@upm.edu.my; yatiramli98@gmail.com
(Han et al., 2014). Among the well-characterised CDs which are $\alpha$-, $\beta$ - and $\gamma$-CDs, $\beta$-CD has been extensively used due to its hydrophobic internal cavity and hydrophilic outer surface which provides water soluble properties (Wang et al., 
2017). The predominant production of $\beta-C D$ is of interest that can reduce the time and cost of purification (Al-Sharawi et al., 2013; Cheirsilp et al., 2010). $\beta$-CD has been frequently employed to form inclusion complexes with a variety of guest molecules, for instance to encapsulate antimicrobial compounds for the development of antimicrobial active packaging materials (Abarca et al., 2016), development of CD nanoparticles to be used in drug delivery systems (Lakkakula and Maçedo Krause, 2014), development of CDbased nanosponges to be used as innovative carriers in cosmetics, pharmaceutical, agrochemistry and environmental protection (Atul and Bhushan, 2017) and many others.

However, large amounts of $\beta$-CGTase are necessary for an effective production of $\beta$-CD through enzymatic synthesis. The low specific activity of the $\beta$-CGTase synthesised by the natural host cells is the main drawback in the production of $\mathrm{CD}$ at a larger scale. Therefore, the need for enhancement of the CGTase properties has become increasingly necessary to improve its quantity and quality for efficient use in industrial applications. According to Qi and Zimmermann (2005), about $50 \%$ of commercialised CGTases were produced through genetic engineering approach. Although a lot of progress has been made to overproduce the enzyme mainly through the development of secretory expression system in E. coli as the common expression platform (Zhou et al., 2018), further research on the enhancement of extracellular secretion of CGTase is needed to improve CD production.

The use of E. coli as a cell factory is preferred as the genetic properties are well established, simple, inexpensive and fast high-density cultivation (Sørensen and Mortensen, 2005). However, the formation of inclusion bodies, poor growth of host and protein inactivity (Rosano and Ceccarelli, 2014) are the critical issues that need to be tackled in order to produce the recombinant enzymes from E. coli effectively. The formation of inclusion bodies could block the translocation channels of pre-proteins and eventually delaying protein secretion (Li et al., 2014). An inadequate release of $\beta$-CGTase across two cell membranes of $E$. coli is the main challenge in order to achieve higher enzyme secretion ( $\mathrm{Li}$ et al., 2010). Therefore, it was suggested that a balance between the rate of pre-protein synthesis and translocation needs to be maintained for an efficient secretion of extracellular enzyme from $E$. coli.

The optimization of the cultivation process has been frequently employed to increase the level of extracellular production of CGTase (Cheng et al., 2011). The use of inducers presents significant advantages in modifying the integrity of the cell wall of E. coli, hence promoting the secretion of recombinant enzyme to the culture medium. The extracellular secretion of the recombinant enzyme from E. coli is preferred over periplasmic and cytoplasmic expression, mainly due to high expression level, the benefit of simple and inexpensive downstream processing (Tesfai et al., 2012), substantial yields of correctly formed proteins and to minimise and avoid protease attack (Choi and Lee, 2004). In the present study, we emphasised on the optimisation of the inducer feeding strategy and attempted to enhance the secretion of recombinant $\beta$-CGTase to the culture medium by adding glycine, Triton X-100 or xylose. This study was also intended to address the effect of inducer supplementation on the cell viability where healthy cell growth is required to enhance the secretion of $\beta$-CGTase.

\section{MATERIALS AND METHODS}

Bacterial strain and plasmid. E. coli JM109 harbouring pTZCGT-BS from previous study (Ramli et al., 2013) was used for sub-cloning into pQE30xa. E. coli JM109 [endA1, recA1, gyrA96, thi, bsdR17 (rk-,mk+), relA1, supE44, D (lac-proAB), F' (tra D36, pro AB, lacIqZ $\Delta$ M15)] from Promega (Madison, WI) was used as a host strain that is ideal for propagating $\mathrm{PQE}$ plasmids and used as an expression host. Plasmid pQE30xa from QIAGEN (Germany) was used as an expression vector.

Construction of $\beta-C G T$ ase expression system. The amplified PCR fragment encoding the $\beta$-CGTase gene was ligated into pQE30xa vector, designated as pQECGT-BS. The amplification of $\beta$-CGTase gene was performed under standard PCR conditions with 1 $\mu \mathrm{g}$ of genomic DNA, 200 gmol of each forward and reverse primer, $0.01 \mu \mathrm{L}$ of Taq DNA polymerase in $1 \times$ reaction buffer and $0.2 \mathrm{mM}$ of dNTPs in a final volume of $20 \mu \mathrm{L}$. The specific primers designed for 
amplification of CGTase used for construction of pQECGT-BS expression system were ProB 5'-T'TA GGA TCC TTG CTC TAG ATT GAT CAA CCA-3' and P2 5'-GTC AAG CTT TTA CCA ATT AAT CAT AAC CGT -3 ' for forward and reverse primer, respectively. The forward and reverse primers were designed to contain the restriction site $\mathrm{Bam} \mathrm{HI}$ and HindIII (underlined), respectively. The amplified DNA fragment was purified after agarose gel electrophoresis using Hi Yield Gel/PCR DNA Mini Kit (Real Biotech Corporation, Taiwan) and digested with BamHI and HindIII before ligation into pQE30xa. To study the expression levels, the ligation products were subsequently introduced into E. coli JM109. Luria-Bertani (LB)-ampicillin (100 $\mu \mathrm{g} / \mathrm{mL})$ was used to plate out the transformation mixtures. After overnight growth at $37^{\circ} \mathrm{C}$, colonies were chosen for insert confirmation.

$\beta$-CGTase expression in E. coli. Recombinant E. coli JM109 harbouring pQECGT-BS was inoculated into LB broth containing $100 \mu \mathrm{g} / \mathrm{mL}$ ampicillin and incubated overnight at $37^{\circ} \mathrm{C}$ in an incubator shaker agitated at $200 \mathrm{rpm}$ until an optical density of 1.5 at $600 \mathrm{~nm}$ was obtained. Terrific Broth (TB) supplemented with 100 $\mu \mathrm{g} / \mathrm{mL}$ ampicillin was used as a production medium for the preparation of crude recombinant $\beta$-CGTase. The culture was incubated at $37^{\circ} \mathrm{C}$, agitated at $200 \mathrm{rpm}$ for $24 \mathrm{~h}$ and sampled every 4 h. Cell-free supernatant was collected by centrifuging at $10000 \mathrm{rpm}$ at $4^{\circ} \mathrm{C}$ for $10 \mathrm{~min}$ to determine the profile of enzyme expression. For estimation of cell growth, the pellets were appropriately diluted and the optical density was measured at $\mathrm{OD}_{600} \mathrm{~nm}$.

\section{Effects of the induction strategies on $\beta$ -} CGTase production. TB media supplemented with either glycine, Triton X-100 or xylose were used to investigate the effects of inducers on the extracellular secretion of the recombinant $\beta$ CGTase. Furthermore, the effects of selected inducer supplementation time $(0,1,2,3$ and $4 \mathrm{~h})$, supplement concentrations $(0.1,0.4,0.8,1.2$ and $1.6 \mathrm{mM})$ and post-induction temperatures $(25,30$, 47 and $40^{\circ} \mathrm{C}$ ) were determined. The experiments were carried out in triplicates.

Flow cytometry sample preparation. The culture broth was diluted at least 1:10 (v/v) in order to obtain a measurement range of less than 1000 cells/second (Falcioni et al., 2008). The diluted broth was filtered using $40 \mu \mathrm{m}$ Nylon cell strainer (Falcon, NJ, USA) to minimise the possibility of causing a clog in the flow cytometer, followed by vortex for at least five min.

Fluorescent probes and staining procedure. A nucleic acid double staining assay (Barbesti et al., 2000) was applied to distinguish between the populations of viable and dead cells. A $42 \mu \mathrm{mol} / \mathrm{L}$ of thiazole orange diluted in dimethyl sulfoxide and $4.3 \mathrm{mmol} / \mathrm{L}$ propidium iodide diluted in distilled water (BD ${ }^{\mathrm{TM}}$ Cell Viability Kit) were used. The unstained samples were prepared as a control to eliminate the assay background noise. The stained samples were instead prepared by adding $5 \mu \mathrm{L}$ of each dye into $500 \mu \mathrm{L}$ of cell suspension to achieve a final concentration of $43 \mu \mathrm{mol} / \mathrm{L}$ for propidium iodide and $420 \mathrm{nmol} / \mathrm{L}$ for thiazole orange, respectively. Further to that, both stained and unstained samples were added with $5 \mu \mathrm{L}$ of EDTA $(1 \mathrm{mM}, \mathrm{pH})$. The staining process was carried out following the manufacturer's protocol of the BD ${ }^{\text {TM }}$ Cell Viability Kit (Cat. No. 349483, Becton Dickinson, San Jose, CA). The samples were incubated in an ice box on an orbital shaker for one hour. A control for the gating process was prepared by heat treatment (Sharuddin et al., 2018) whereby $50 \mathrm{~mL}$ of the samples were heated at 80 to $90^{\circ} \mathrm{C}$ in a water bath for $45 \mathrm{~min}$.

Flow cytometric analyses. The flow cytometric analyses were done using a BD Accuri® C6 cytometer (Becton Dickinson UK Ltd., Oxford, $\mathrm{UK})$ equipped with red $(640 \mathrm{~nm})$ and blue (488 $\mathrm{nm}$ ) lasers, forward-scattered (FSC) and sidescattered light (SSC) and four fluorescence detectors. The propidium iodide fluorescence was collected at the FL3 channel, while the thiazole orange fluorescence was collected at the FL1 channel, with 20,000 cells counted for each sample. The differentiation between viable and dead cells was done through a gating on a dot plot of red versus green fluorescence after excluding the auto-fluorescence. The visualisation of the plots and the gating process were done using the built in CFlow Plus software. The repeated measurements Analysis of Variance (ANOVA) were conducted to test for significant differences of viable and dead cells between no induction, $0 \mathrm{~h}$ and $2 \mathrm{~h}$ induction with glycine. 
Purification of $\beta$-CGTase. The crude $\beta$-CGTase was washed with equilibrium buffer $(10 \mathrm{mM}$ imidazole) with molecular weight cut-off (MWCO) of $30 \mathrm{kDa}$ using AKTA Flux tangential flow filtration system (GE Healthcare, USA). Affinity purification was performed on a Ni-NTA column on an AKTA Avant chromatography system (GE Healthcare, USA) according to the manufacturer's instructions. The sample was incubated for $30 \mathrm{~min}$ in the column, followed by washing with buffer containing $20 \mathrm{mM}$ imidazole (pH 8.0). Elution buffer containing $250 \mathrm{mM}$ imidazole ( $\mathrm{pH}$ 8.0) was used to elute the bound enzyme. The fractions with maximum activity were pooled together and concentrated using Amicon ultrafiltration membrane kit $(30 \mathrm{kDa}$ MWCO membrane). The samples were assayed for $\beta$-CGTase activity and protein concentration.

\section{Determination of protein concentration and} size. Protein concentration was measured using Lowry method (Lowry et al., 1951) with bovine serum albumin as a standard. The protein size was analysed using sodium dodecyl sulfatepolyacrylamide gel electrophoresis (SDS-PAGE) at constant voltage of $100 \mathrm{~V}$ for $1.5 \mathrm{~h}$ at room temperature until the band was migrated sufficiently. Gel $(8.3 \mathrm{~cm} \mathrm{X} 7.3 \mathrm{~cm})$ was run according to the method of Laemmli (1970). The concentrations of the stacking and resolving gels were $5 \%$ and $12 \%$, respectively. Appropriately diluted protein samples $(30 \mu \mathrm{g})$ with $4 \times$ marker containing $50 \mathrm{mM}$ Tris- $\mathrm{HCl}(\mathrm{pH}$ 6.8), 40\% (w/v) of glycerol, $10 \%(\mathrm{w} / \mathrm{v})$ of SDS, $5 \%(\mathrm{v} / \mathrm{v})$ of mercaptoethanol and $0.05 \% \quad(\mathrm{w} / \mathrm{v})$ of bromophenol blue were boiled for $5 \mathrm{~min}$ before applied into each lane. The lane was formed by a 10-well comb (Mini-PROTEAN ${ }^{\circledR}$ ) and the molecular weight marker (PageRuler ${ }^{\mathrm{TM}}$ Unstained Protein Ladder) from Thermo Scientific, USA was used as a standard. The gel was stained with Coomassie Brilliant Blue R-250.

$\beta$-CGTase activity. The $\beta$-CGTase activity was measured using phenolphthalein assay (Kaneko et al., 1987). Reaction mixture containing $1 \mathrm{~mL}$ of 40 mg of soluble starch in $100 \mathrm{mM}$ phosphate buffer $(\mathrm{pH}$ 6.0) and $0.1 \mathrm{~mL}$ of $\beta$-CGTase solution was incubated at $60^{\circ} \mathrm{C}$ for $10 \mathrm{~min}$ in a water bath. The reaction was stopped by the addition of $3.5 \mathrm{~mL}$ of $30 \mathrm{mM} \mathrm{NaOH}$. Subsequently, $0.5 \mathrm{~mL}$ of $0.02 \%$ (w/v) phenolphthalein in $5 \mathrm{mM} \mathrm{Na}_{2} \mathrm{CO}_{3}$ solution was added to the reaction mixture and mixed well. After $15 \mathrm{~min}$, the reduction in colour intensity was measured at $550 \mathrm{~nm}$. Blank lacking the CGTase was analysed simultaneously with each batch of samples. As a standard, the soluble starch and enzyme were replaced with $1 \mathrm{~mL}$ of $\beta-\mathrm{CD}$ solution and $0.1 \mathrm{~mL}$ of water, respectively. A calibration curve was made using $0-0.5 \mathrm{mg} / \mathrm{mL}$ of $\beta$-CD in $100 \mathrm{mM}$ phosphate buffer, $\mathrm{pH}$ 6.0. One unit of enzyme activity was defined as the amount of enzyme that formed $1 \mu \mathrm{mol}$ of $\beta$-CD per min under the conditions defined above.

Production of cyclodextrin and kinetic parameters. The kinetic parameters, $K_{m}$ and $V_{\max }$ of the recombinant $\beta$-CGTase were analysed by linear regression with the linear transformation (Hanes-Woolf plot) of the Michaelis-Menten equation using an Excel curve-fitting program (Microsoft Excel 2010, San Francisco, CA, USA). The $K_{m}$ and $V_{\max }$ values for the recombinant $\beta$ CGTase were determined by incubating 0.5 $\mathrm{U} / \mathrm{mL}$ of $\beta$-CGTase with $2-10 \mathrm{mg} / \mathrm{mL}$ of soluble starch at $60^{\circ} \mathrm{C}$ for $10 \mathrm{~min}$ in $1 \mathrm{~mL}$ of $0.1 \mathrm{M}$ phosphate buffer (according to standard $\beta$ CGTase assay) (Kaneko et al., 1987). The concentrations of $\beta-C D$ were determined by high performance liquid chromatography (HPLC) using a Lichrospher $100 \mathrm{NH}_{2}$ column (Merck, USA) eluted with $65: 35$ acetonitrile:water mixture at $1 \mathrm{~mL} / \mathrm{min}$. $\beta$-CD was detected by a refractive index detector (Shimadzu, Japan). The experiments were carried out in triplicates and standard deviations were calculated.

\section{RESULTS AND DISCUSSION}

\section{Construction of recombinant plasmid and} production of $\beta$-CGTase. The cgt gene was constructed in $\mathrm{pQE} 30 \mathrm{xa}$ and in frame with $6 \mathrm{x}-\mathrm{His}$ tag to assist in protein purification using affinity chromatography. The expression vector was successfully constructed and verified by sequencing before it was transformed into E. coli JM109. The resulting strains exhibited 30.371 $\mathrm{U} / \mathrm{mL}$ of $\beta$-CGTase activity from the supernatant without any inducer (Figure 1), a 2.6-fold increment of $\beta$-CGTase activity as compared to 
wild type producer (Ramli et al., 2010). The same cgt gene was previously constructed in $\mathrm{pTZ}$ T7R/T and expressed in E. coli JM 109 with the activity of $37.480 \mathrm{U} / \mathrm{mL}$ (Ramli et al., 2013). A low enzyme activity detected in the culture medium of E. coli without inducer might be due to the accumulation of protein in the periplasmic space (Li et al., 2010). However, the disruption of outer membrane to recover the target protein is not preferred as it may cause the intracellular proteolysis by periplasmic proteases (Choi and Lee, 2004). Moreover, it could also result in cell death and injury, for instance by introducing high pressure to E. coli cells to recover proteins (Hauben et al., 1996). The disruption of outer membrane of $E$. coli for the recombinant protein production needs to be handled with care so as not to compromise cellular integrity.

\section{Effects of inducers on extracellular secretion} of $\boldsymbol{\beta}$-CGTase. Three types of inducers were selected to enhance the extracellular secretion of $\beta$-CGTase from E. coli which were glycine, Triton $\mathrm{X}-100$ and xylose, in comparison to control culture without any inducer. The glycine, Triton X-100 and xylose were known to have different effects on the integrity of the cell wall of E. coli $(\mathrm{Li}$ et al., 2014, 2010; Lo et al., 2007). The supplementation of inducers during cultivation offers advantages as compared to the physical methods including osmotic shock, sonication and freezing and thawing where they can only be applied after harvesting cells. Therefore, by adopting the inducer feeding strategy, the additional steps of recombinant proteins recovery after the fermentation process are not necessary.

The induction by glycine increased the extracellular secretion of $\beta$-CGTase activity at 12 $\mathrm{h}$ of fermentation by 1.1 -fold, while the Triton $\mathrm{X}$ 100 and xylose induction showed negative effects (Figure 1A). ANOVA test was conducted in this study and demonstrated significant differences of $\beta$-CGTase activities between the use of different types of inducers at a confidence level of 0.05 $(p<0.05)$. Glycine's capability to act as a permeability enhancer, resulted in the increased activity of recombinant $\beta$-CGTase. The glycine could replace the alanine residues in the peptide component of the peptidoglycan of E. coli cell wall, resulting in a more loosely cross-linked peptidoglycan and therefore, enhancing the permeability of outer membrane of E. coli (Yang et al., 2017). The glycine was previously shown to increase the secretion of extracellular $\alpha$-CGTase from $E$. coli by 11 -fold to achieve maximum activity of $28.5 \mathrm{U} / \mathrm{mL}$ (Li et al., 2010). However, the supplementation of Triton X-100 and sucrose might have compromised the cellular integrity and the growth of E. coli, which resulted in the reduced activity of extracellular $\beta$-CGTase. The glycine was thus selected to be used in the optimisation of inducer feeding strategy by single factor design to further increase the extracellular secretion of $\beta$ CGTase.

\section{Effect of glycine feeding strategy on extracellular secretion of $\beta-C G$ Tase. The effect} of glycine supplement time was conducted to enhance the extracellular secretion of recombinant $\beta$-CGTase from E. coli (Figure 1B). The addition of $0.1 \mathrm{M}$ glycine at $2 \mathrm{~h}$ fermentation has resulted in the 1.1-fold increment of enzyme activity at $12 \mathrm{~h}$ of incubation as compared to the induction at the beginning of the culture. The induction at $2 \mathrm{~h}$ during early log phase might have increase the leakage of periplasmic proteins to the culture medium, which resulted in the increased activity of $\beta$-CGTase. According to Li et al. (2010), cell growth impairment caused by glycine could be controlled by delaying the addition of glycine to the culture medium. However, reduction of $\beta$ CGTase activities was recorded by increasing the timing of induction to 3 and $4 \mathrm{~h}$ of fermentation. The induction at high cell density during stationary phase is not recommended due to the bacterial cell membrane rigidity (Bao et al., 2016).

The amount of glycine necessary to enhance the permeability of outer membrane of $E$. coli was $1.2 \mathrm{mM}$ and showed enhancement of $\beta$-CGTase activity by 1.3 -fold as compared to the culture without inducer (Figure 1C). However, the supplementation of $1.6 \mathrm{mM}$ glycine inhibited the $\beta$-CGTase activity and an excessive amount of glycine is unfavorable to the cell and might inhibit the bacterial growth (Zou et al., 2014). In addition, an approach to increase the production of recombinant proteins by lowering the induction temperature is frequently reported (Lu et al., 2018; Zheng et al., 2016). Although the enzyme expression could be significantly enhanced at lower induction temperature to increase the formation of correctly folded protein, this study 
found opposing results where the incubation at $25^{\circ} \mathrm{C}$ caused a reduction of enzyme activity by $2.4-$ fold as compared to the incubation at $37^{\circ} \mathrm{C}$ (Figure 1D). Low incubation temperature at $25^{\circ} \mathrm{C}$

(A)

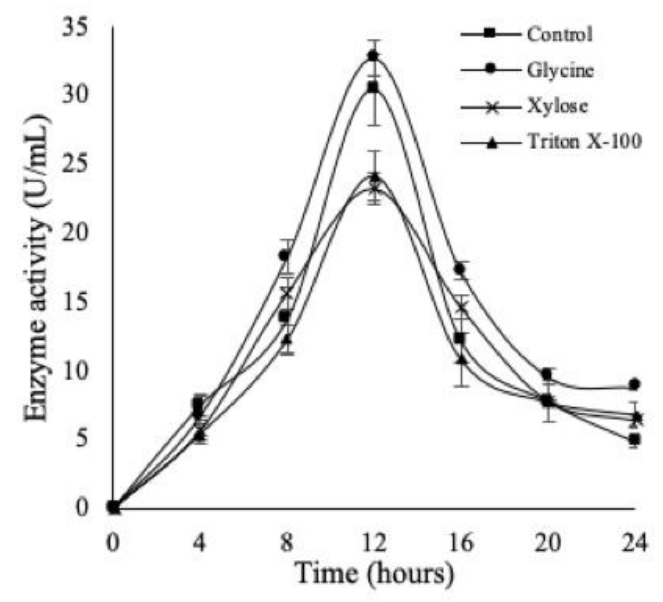

(C)

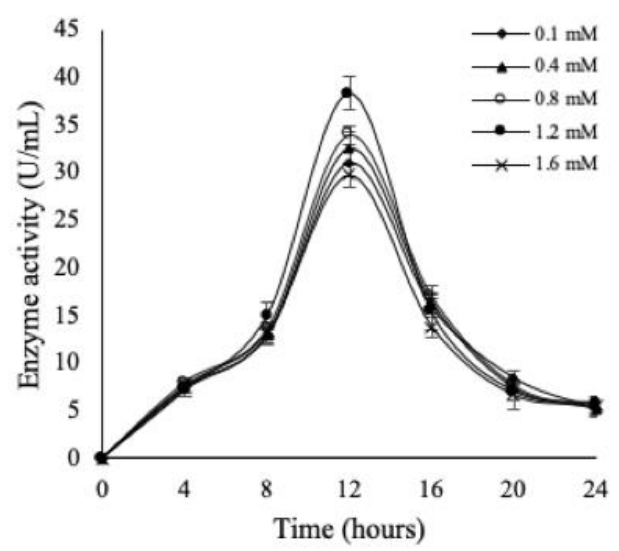

might contribute to the impaired growth of E. coli (Chang et al., 2017), hence reducing the activity of $\beta$-CGTase.

(B)

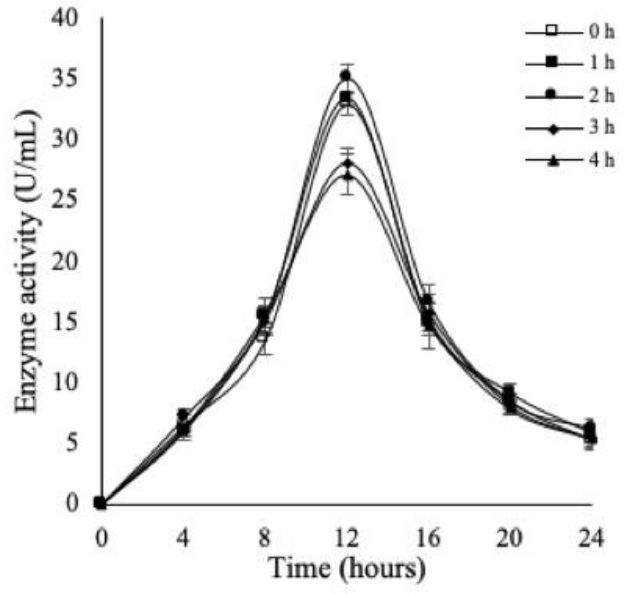

(D)

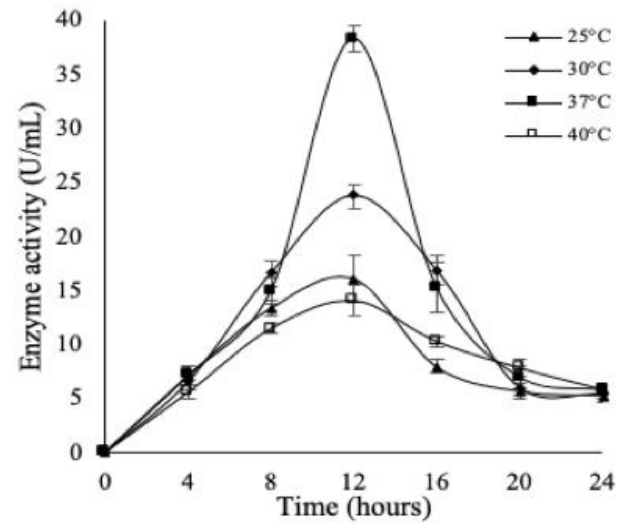

Figure 1. Effects of different types of inducers (A); glycine supplement time (B); glycine concentrations (C); post-induction temperatures (D) on the extracellular secretion of $\beta$-CGTase from E. coli harbouring pQECGT-BS. Each value represents the mean of three independent measurements and the deviation from the mean is below $5 \%$.

Effect of glycine supplementation on cell viability. To confirm the secretion of $\beta$-CGTase is not due to the cell lysis, the live and dead cells were quantified by using nucleic acid double staining assay based on flow cytometry. The secretion of enzyme into the culture medium via cell lysis is undesirable due to the release of proteins and other contaminants from the intracellular space (Shin and Chen, 2008), which might interfere in the purification process. Although different methods were reported to indicate for cell lysis, for instance by determination of cytoplasmic proteins; $\beta$ galactosidase (Bao et al., 2016) and glucose-6phosphate dehydrogenase (Li et al., 2010) that are expected to be present in very low concentration in the culture medium, they differ in respect to sensitivity and accuracy. In this study, a flow cytometry method was adopted to quantify the concentrations of live and dead cells where it considered as a rapid, sensitive and highly reproducible approach (Fontana et al., 2017). This 
approach could also replace the cells quantification method under microscopy that is time-consuming and lacks reproducibility.

(a)

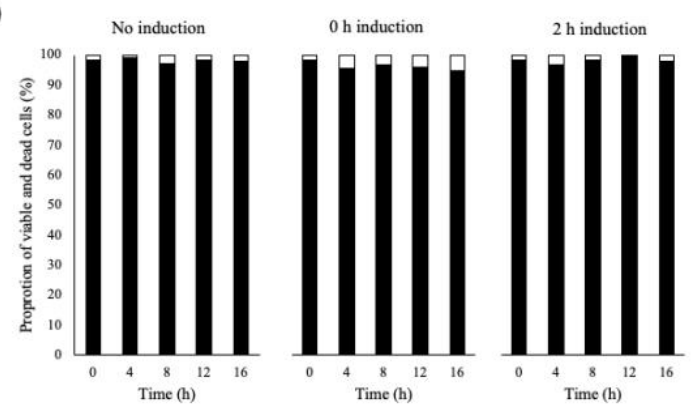

(b)
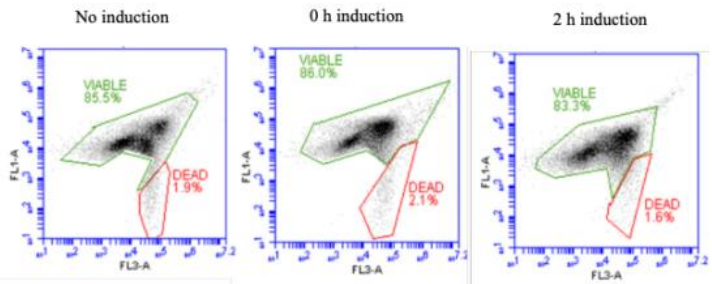

Figure 2. (A) Proportion of viable ( $\mathbf{\square}$ ) and dead () cells of E. coli harbouring pQECGT-BS throughout $16 \mathrm{~h}$ of fermentation; (B) Representative flow cytometry dot plots showing distribution of dead and viable cells of recombinant E. coli with no induction as a control and inductions with $1.2 \mathrm{mM}$ of glycine at $0 \mathrm{~h}$ and $2 \mathrm{~h}$. An ANOVA test demonstrated a significant difference of viable and dead cells between no induction, $0 \mathrm{~h}$ and $2 \mathrm{~h}$ induction with glycine at $p<0.05$.

As shown in Figure 2, the addition of $1.2 \mathrm{mM}$ glycine at 2-h of fermentation did not show any apparent effect on the viability of the E. coli cells where the percentage of viable cells recorded was more than $97 \%$, comparable with the viable cells in the culture without any inducer. Only a slight reduction of the percentage of viable cell was recorded with the addition of $1.2 \mathrm{mM}$ glycine at the beginning of the culture. A higher percentage of live cells recorded following glycine induction indicates the release of recombinant $\beta$-CGTase was due to the interference of glycine with the membrane integrity and not due to cell lysis.

\section{Purification and kinetic parameters for determination of the recombinant $\beta-C G$ Tase.} The recombinant $\beta$-CGTase was collected and purified from the 12 -h culture induced with 1.2 $\mathrm{mM}$ glycine at $2 \mathrm{~h}$ induction time at $37^{\circ} \mathrm{C}$. The recombinant $\beta$-CGTase carried an $\mathrm{N}$-terminal fusion peptide containing a $6 \mathrm{x}-\mathrm{His}$ sequence that provides metal-binding affinity. Therefore, it was purified through a combination of diafiltration and Ni-NTA affinity chromatography, which resulted in increased purity to 18.4-fold. Ultrafiltration was then applied to concentrate the protein where the purity was increased to 21.6fold (Table 1). To evaluate the purity of protein, the diafiltrated and purified proteins were resolved by SDS-PAGE. The results showed the expected size band of the purified protein of 78.6 $\mathrm{kDa}$ (Figure 3).
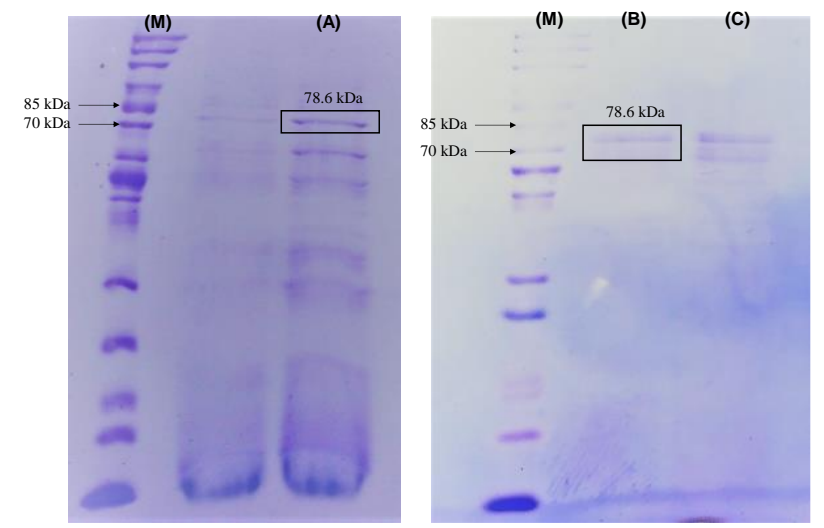

Figure 3. SDS-PAGE analysis of the (A) crude protein; (B) purified protein; and (C) diafiltrated protein. The protein samples were loaded with the total concentration of $30 \mu \mathrm{g}$ for each well. M: PageRuler unstained protein leader (Thermo Fisher Scientific, USA).

Furthermore, a different range of soluble starch concentrations was tested to produce $\beta-C D$ by $\beta$-CGTase. A maximum $\beta$-CD of 16.671 $\mathrm{mg} / \mathrm{mL}$ was achieved by using $4 \mathrm{mg} / \mathrm{mL}$ of starch (Figure 4). However, the production of $\beta-C D$ was reduced and attained almost a similar concentration with increased starch concentration. At these points, the enzyme could probably has reached saturation with the substrate (Robinson, 2015). The cyclisation reaction of $\beta$ CGTase was then described by MichaelisMenten kinetic parameters (Figure 5) to evaluate the performance of recombinant $\beta$-CGTase for $\beta$ CD production (Chen et al., 2018; Rakmai and Cheirsilp, 2016). The $V_{\max }$ and $K_{m}$ values were evaluated to be $1.3 \mathrm{mg} / \mathrm{mL} / \mathrm{min}$ and 0.025 $\mathrm{mg} / \mathrm{mL}$, respectively. A small value of $K_{m}$ could indicate a high affinity for the substrate (Ong et al., 2008). Hence, it was suggested that the recombinant $\beta$-CGTase was specific towards 
starch and could achieve its maximum catalytic efficiency at low starch concentrations.

Table 1 Purification yield of recombinant $\beta$-CGTase from E. coli following induction with $1.2 \mathrm{mM}$ glycine at $2 \mathrm{~h}$ of fermentation at $37^{\circ} \mathrm{C}$.

\begin{tabular}{cccccc}
\hline $\begin{array}{c}\text { Purification } \\
\text { steps }\end{array}$ & $\begin{array}{c}\boldsymbol{\beta} \text {-CGTase } \\
\text { activity } \\
(\mathbf{U} / \mathbf{m L})\end{array}$ & $\begin{array}{c}\text { Protein } \\
\text { concentration } \\
\mathbf{( m g} / \mathbf{m L})\end{array}$ & $\begin{array}{c}\text { Specific activity } \\
\mathbf{( U / m g )}\end{array}$ & $\begin{array}{c}\text { Purification } \\
\text { (fold) }\end{array}$ & Yield (\%) \\
\hline Crude & $38.585 \pm 1.513$ & $16.175 \pm 0.702$ & $2.385 \pm 0.197$ & 1 & 100 \\
\hline Diafiltration & $31.354 \pm 0.877$ & $10.189 \pm 0.456$ & $3.077 \pm 0.052$ & 1.290 & 81.26 \\
\hline $\begin{array}{c}\text { Affinity } \\
\text { chromatography }\end{array}$ & $19.953 \pm 0.143$ & $0.455 \pm 0.026$ & $43.882 \pm 2.821$ & 18.395 & 51.71 \\
\hline Ultrafiltration & $8.361 \pm 0.088$ & $0.163 \pm 0.029$ & $51.408 \pm 3.021$ & 21.550 & 21.67 \\
\hline
\end{tabular}

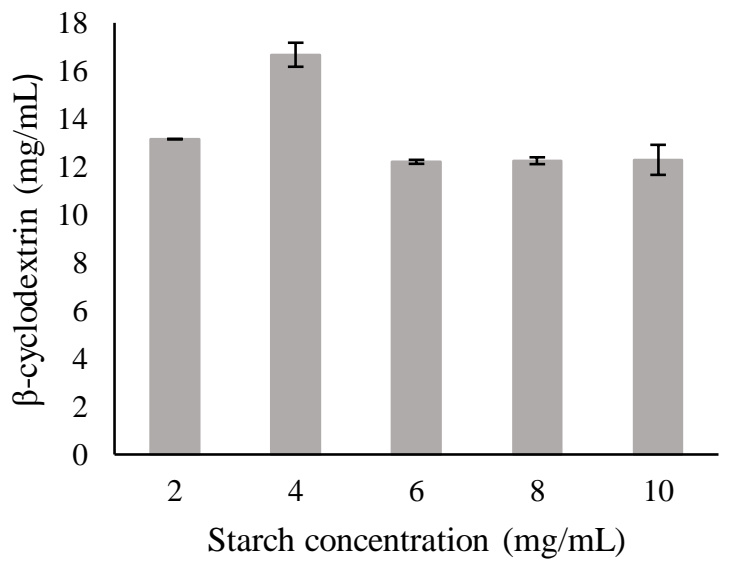

Figure 4. The production of $\beta$-cyclodextrin by purified $\beta$-CGTase using different starch concentrations. Standard deviations are shown as bars and the deviation from the mean is below $5 \%$.

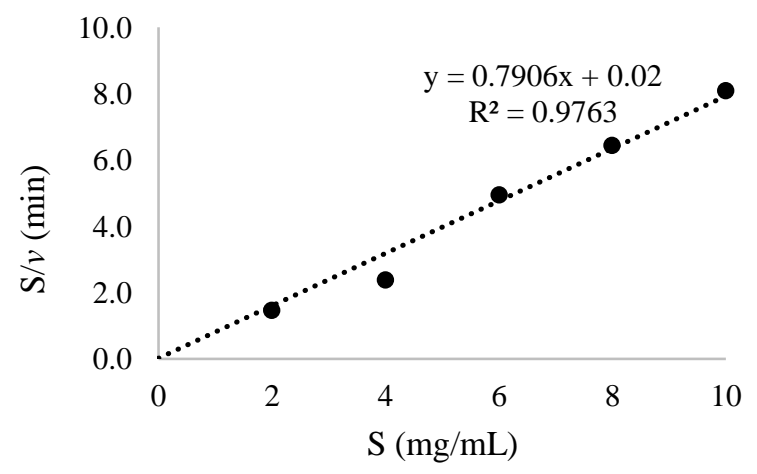

Figure 5. The Hanes-Woolf plot to identify $K_{m}$ and $V_{\max }$ which were used in the MichaelisMenten equation. S: substrate, $v$ : velocity.

\section{CONCLUSION}

As a conclusion, the present study demonstrated that the supplementation of glycine with correct feeding strategy could enhance the secretion of $\beta$ CGTase into the culture medium of $E$. coli without any adverse effect on the viability of $E$. coli cells. This feeding strategy could be applied to enhance the extracellular secretion of a recombinant protein from $E$. coli system at the cultivation process.

\section{ACKNOWLEDGEMENT}

This project was funded by the Fundamental Research Grant Scheme (FRGS/2/2013/SG05/ $\mathrm{UPM} / 02 / 17$ ) provided by the Ministry of Education, Malaysia. Nik-Pa, N.I.M. gratefully acknowledges Universiti Kuala Lumpur (UniKL) and Majlis Amanah Rakyat (MARA) for the provision of study leave and scholarship. The authors also acknowledge the contribution of Mohd Azizan Mohd Noor in the kinetics study.

\section{REFERENCES}

Abarca, R.L., Rodriguez, F.J., Guarda, A., Galotto, M.J. and Bruna, J.E. 2016. Characterization of beta-cyclodextrin inclusion complexes containing an essential oil component. Food Chemistry 196: 968-975.

Al-Sharawi, S.Z.R., Ibrahim, A.S.S., El-Shatoury, E.H., Gebreel, H.M. and Eldiwany, A. 2013. A new low molecular mass alkaline cyclodextrin glucanotransferase from Amphibacillus sp. NRC-WN isolated from an Egyptian soda lake. Electronic Journal of Biotechnology 16: 1-13.

Atul, P. and Bhushan, R. 2017. Cyclodextrin-based nanosponges: A critical review. Carbobydrate Polymers 173: 37-49. 
Bao, R., Yang, H., Yu, C., Zhang, W. and Tang, J. 2016. An efficient protocol to enhance the extracellular production of recombinant protein from Escherichia coli by the synergistic effects of sucrose, glycine, and Triton X-100. Protein Expression and Purification 126: 9-15.

Barbesti, S., Citterio, S., Labra, M., Baroni, M.D., Neri, M.G. and Sgorbati, S. 2000. Two and three-color fluorescence flow cytometric analysis of immunoidentified viable bacteria. Cytometry 40: 214-218.

Chang, S., Guo, Y., Wu, B. and He, B. 2017. Extracellular expression of alkali tolerant xylanase from Bacillus subtilis Lucky9 in E. coli and application for xylooligosaccharides production from agro-industrial waste. International Journal of Biological Macromolecules 96: 249-256.

Cheirsilp, B., Kitcha, S. and Maneerat, S. 2010. Kinetic characteristics of $\beta$-cyclodextrin production by cyclodextrin glycosyltransferase from newly isolated Bacillus sp. C26. Electronic Journal of Biotechnology 13(4): 4-5.

Chen, S., Li, Z., Gu, Z., Hong, Y., Cheng, L., Holler, T.P. and Li, C. 2018. Leu600 mutations decrease product inhibition of the $\beta$-cyclodextrin glycosyltransferase from Bacillus circulans STB01. International Journal of Biological Macromolecules 115: 1194-1201.

Cheng, J., Wu, D., Chen, S., Chen, J. and Wu, J. 2011. High-level extracellular production of $\alpha$-cyclodextrin glycosyltransferase with recombinant Escherichia coli BL21 (DE3). Journal of Agricultural and Food Chemistry 59: 37973802.

Choi, J.H. and Lee, S.Y. 2004. Secretory and extracellular production of recombinant proteins using Escherichia coli. Applied Microbiology and Biotechnology 64: 625-635.

Falcioni, T., Papa, S. and Gasol, J.M. 2008. Evaluating the flowcytometric nucleic acid double-staining protocol in realistic situations of planktonic bacterial death. Applied and Environmental Microbiology 74: 1767-1779.

Fontana, C., Crussard, S., Simon-Dufay, N., Pialot, D., Bomchil, N. and Reyes, J. 2017. Use of flow cytometry for rapid and accurate enumeration of live pathogenic Leptospira strains. Journal of Microbiological Methods 132: 34-40.

Han, R., Li, J., Shin, H.-D., Chen, R.R., Du, G., Liu, L. and Chen, J. 2013. Recent advances in discovery, heterologous expression, and molecular engineering of cyclodextrin glycosyltransferase for versatile applications. Biotechnology Advances 32(2): 415-428.

Hauben, K.J.A., Wuytack, E.Y., Soontjens, C.C.F. and Michiels, C.W. 1996. High-pressure transient sensitization of Escherichia coli to lysozyme and nisin by distuption of outermembrane permeability. Journal of Food Protection 59: 350355.

Kaneko, T., Kato, T., Nakamura, N. and Horikoshi, K. 1987. Spectrophotometric determination of cyclization activity of $\beta$-cyclodextrin-forming cyclomaltodextrin glucanotransferase. Journal of the Japanese Society of Starch Science 34: 45-48.

Laemmli, U.K. 1970. Glycine-SDS-PAGE for separation of proteins. Nature 227(5).

Lakkakula, J.R. and Maçedo Krause, R.W. 2014. A vision for cyclodextrin nanoparticles in drug delivery systems and pharmaceutical applications. Nanomedicine 9: 877-894.

Li, Z., Gu, Z., Wang, M., Du, G., Wu, J. and Chen, J. 2010. Delayed supplementation of glycine enhances extracellular secretion of the recombinant $\alpha$-cyclodextrin glycosyltransferase in Escherichia coli. Applied Microbiology and Biotechnology 85: 553561.

Li, Z., Su, L., Wang, L., Liu, Z., Gu, Z., Chen, J. and Wu, J. 2014. Novel insight into the secretory expression of recombinant enzymes in Escherichia coli. Process Biochemistry 49: 599-603.
Lo, P.K., Hassan, O., Ahmad, A., Mahadi, N.M. and Illias, R.M. 2007. Excretory over-expression of Bacillus sp. G1 cyclodextrin glucanotransferase (CGTase) in Escherichia coli: Optimization of the cultivation conditions by response surface methodology. Enayme and Microbial Technology 40: 1256-1263.

Lowry, O.H., Randall, R.J., Rosebrough, N.J. and Farr, A.L. 1951. Protein measurement with the folin phenol reagent. The Journal of Biological Chemistry 193: 265-275.

Lu, J., Zhao, Y. and Zhang, J. 2018. High-level expression of Aerococcus viridans pyruvate oxidase in Escherichia coli by optimization of vectors and induction conditions. Letters in Applied Microbiology 67: 262-269.

Ong, R.M., Goh, K.M., Mahadi, N.M., Hassan, O., Rahman, R.N.Z.R.A. and Illias, R.M. 2008. Cloning, extracellular expression and characterization of a predominant betaCGTase from Bacillus sp. G1 in E. coli. Journal of Industrial Microbiology and Biotechnology 35: 1705-1714.

Qi, Q. and Zimmermann, W. 2005. Cyclodextrin glucanotransferase: From gene to applications. Applied Microbiology and Biotechnology 66: 475-485.

Rakmai, J. and Cheirsilp, B. 2016. Continuous production of $\beta$ cyclodextrin by cyclodextrin glycosyltransferase immobilized in mixed gel beads: comparative study in continuous stirred tank reactor and packed bed reactor. Biochemical Engineering Journal 105: 107-113.

Ramli, N., Abd-Aziz, S., Alitheen, N.B., Hassan, M.A. and Maeda, T. 2013. Improvement of cyclodextrin glycosyltransferase gene expression in Escherichia coli by insertion of regulatory sequences involved in the promotion of RNA transcription. Molecular Biotechnology 54: 961-968.

Ramli, N., Abd-Aziz, S., Hassan, M.A., Alitheen, N. and Kamaruddin, K. 2010. Potential cyclodextrin glycosyltransferase producer from locally isolated bacteria. African Journal of Biotechnology 9: 7317-7321.

Robinson, P.K. 2015. Enzymes: principles and biotechnological applications. Essays Biochemistry 59: 1-41.

Rosano, G.L. and Ceccarelli, E.A. 2014. Recombinant protein expression in Escherichia coli: advances and challenges. Frontiers in Microbiology 5: 172.

Sharuddin, S.S., Ramli, N., Mohd-Nor, D., Hassan, M.A., Maeda, T., Shirai, Y., Sakai, K. and Tashiro, Y. 2018. Shift of low to high nucleic acid bacteria as a potential bioindicator for the screening of anthropogenic effects in a receiving river due to palm oil mill effluent final discharge. Ecological Indicators 85: 79-84.

Shin, H. and Chen, R.R. 2008. Extracellular recombinant protein production from an Escherichia coli lpp deletion mutant. Biotechnology and Bioengineering 101: 1288-1296.

Sørensen, H.P. and Mortensen, K.K. 2005. Advanced genetic strategies for recombinant protein expression in Escherichia coli. Journal of Biotechnology 115: 113-128.

Tesfai, B.T., Wu, D., Chen, S., Chen, J. and Wu, J. 2012. Strategies for enhancing extracellular secretion of recombinant cyclodextrin glucanotransferase in E. coli. Applied Biochemistry and Biotechnology 167: 897-908.

Wang, H., Zhou, W., Li, H., Rie, B. and Piao, C. 2017. Improved activity of $\beta$-cyclodextrin glycosyltransferase from Bacillus sp. N-227 via mutagenesis of the conserved residues. 3 Biotech 7: 149

Yang, Y., Li, J., Liu, X., Pan, X., Hou, J., Ran, C. and Zhou, Z. 2017. Improving extracellular production of Serratia marcescens lytic polysaccharide monooxygenase CBP21 and Aeromonas veronii $\mathrm{B} 565$ chitinase Chi92 in Escherichia coli and their synergism. AMB Express 7: 170.

Zheng, H., Yu, Z., Fu, X., Li, S., Xu, J., Song, H. and Ma, Y. 2016. High level extracellular production of a truncated alkaline $\beta$-mannanase from alkaliphilic Bacillus sp. N16-5 in 
Escherichia coli by the optimization of induction condition and fed-batch fermentation. Journal of Industrial Microbiology and Biotechnology 43: 977-987.

Zhou, Y., Lu, Z., Wang, X., Selvaraj, J.N. and Zhang, G. 2018. Genetic engineering modification and fermentation optimization for extracellular production of recombinant proteins using Escherichia coli. Applied Microbiology and Biotechnology 102(4): 1545-1556.

Zou, C., Duan, X. and Wu, J. 2014. Enhanced extracellular production of recombinant Bacillus deramificans pullulanase in Escherichia coli through induction mode optimization and a glycine feeding strategy. Bioresource Technology 172: 174 179 . 